\title{
Preventive effect of pomegranate juice on ESWL-related renal damage in patients with kidney stones
}

\section{Böbrek tașı hastalarda ESWL' ye bağlı renal hasar üzerine nar suyunun önleyici etkisi}

\author{
Selim Taş', Volkan Tuğcu², Serdar Karadağ³ , Selçuk \$̦ahin ${ }^{3}$ \\ 1 Antalya Training and Research Hospital, Department of Urology, Antalya, Turkey \\ 2 Live Hospital Beșiktaș, Department of Urology, İstanbul, Turkey \\ 3 Bakırköy Dr. Sadi Konuk Training and Research Hospital, Department of Urology, İstanbul, Turkey
}

Submitted (Gelis tarihi): 2021-07-23 Accepted (Kabul tarihi): 2022-01-02

Correspondence / Yazışma
Selim Taş
Antalya Training and Research Hosp
Department of Urology, Varlık, Kazıı
Karabekir St. 07100
Muratpaşa, Antalya / Turkey
Email: drslmtas@hotmail.com
Tel: +90 2422494400

ORCID
$\begin{aligned} & \text { S.T. } \quad 0000-0001-8492-4603 \\ & \text { V.T. } \quad 0000-0002-4136-7584 \\ & \text { S.K. } \quad 0000-0002-1420-4536 \\ & \text { S.Ş. } \quad 0000-0002-0903-320 \mathrm{X}\end{aligned}$

This work is licensed under a Creative Commons Attribution-NonCommercial 4.0 International License.

\section{Özet}

Amaç: Böbrek taşı tanısı nedeni ile ekstrakorporeal şok dalga litotripsi (ESWL) tedavisi uygulanan hastalarda, ESWL'nin neden olduğu oksidatif stresin yarattı̆̆ böbrek hasarının; nar suyunun (NS) antioksidan etkisiyle tedaviye bağlı böbrek hasarına karşı koruyucu etkisi olup olmadığını göstermeyi amaçladık.

Gereç ve Yöntemler: Böbrek taşı nedeniyle ESWL uygulanacak 90 hasta çalışmaya dahil edildi ve 30 kişiden oluşan 3 gruba ayrıldı. Grup l'deki (kontrol grubu) hastalara sadece ESWL tedavisi uygulandı. Grup 2'deki (çalışma grubu) hastalara ESWL'den 2 gün önce $30 \mathrm{ml} / \mathrm{kg} /$ gün hazırlanan nar suyu karışımı 2 gün oral alınması önerildi. Grup 3'teki (plasebo grubu) hastalara ESWL'den 2 gün önce $30 \mathrm{mg} / \mathrm{kg} /$ gün su oral alınması önerildi. Hastalara 18-24 kV aralığında 2000-2500 atış yapıldı. Oksidatif stres, DNA lezyonunu gösteren lipid peroksidasyonun belirteçleri ve ESWL'den sonra tübüler hasar göstermek amacı ile her üç gruptaki hastalardan ESWL'den 3 gün önce ve hemen sonra 24 saatlik idrar topland 1 ve spot idrar numunesi alındı.

Bulgular: Grup 1'de tedavi sonrası 8-Hydroxy deoxyguanosine (8-OHdG) düzeylerinde

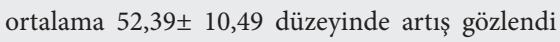
$(\mathrm{p}<0,01)$. Grup 2'de tedavi sonrası 8-OHdG düzeylerinde ortalama $13,16 \pm 7,71$ düzeyinde artış gözlendi $(\mathrm{p}<0,01)$.

Grup l'de tedavi sonrasi N-acetyl-beta-D-glucosaminidase (NAG) düzeylerinde görülen ortalama $19,20 \pm 5,21$ düzeyinde artış göz-

\section{Abstract}

Objective: We aimed to show whether the antioxidant properties of pomegranate juice $(\mathrm{PJ})$ show a protective effect against renal damage associated with oxidative stress caused by Extracorporeal Shock Wave Lithotripsy (ESWL) in patients who have undergone ESWL for kidney stones.

Material and Methods: Ninety patients who were to undergo ESWL for kidney stones were included in the study and were divided into 3 groups with 30 patients each ESWL. Group 1 (control group) patients received only ESWL treatment. Group 2 (study group) patients were recommended to take $30 \mathrm{ml} / \mathrm{kg} /$ day pomegranate juice mixture orally for 2 days before ESWL. Group 3 (placebo group) patients were recommended to take $30 \mathrm{mg} / \mathrm{kg} /$ day water orally for 2 days before ESWL. All ESWL-treated patients received 2000 to 2500 shock waves at 18 to 24 in order to measure lipid peroxidation markers showing the DNA lesion associated with oxidative stress and to show tubular damage after ESWL,

Results: There was a statistically significant mean increase of 52.39 \pm 10.49 in 8-Hydroxy deoxyguanosine (8-OHdG) levels after treatment compared to pre-treatment levels in Group $1(\mathrm{p}<0.01)$. There was a statistically significant mean increase of $13.16 \pm 7.71$ and $33.24 \pm 12.82$ in Groups 2 and 3, respectively ( $\mathrm{p}<0.01 ; \mathrm{p}<0.01$, respectively)

There was a statistically significant mean increase of $19.20 \pm 5.21$ in N-acetyl-beta-D-glucosaminidase (NAG) levels after treatment compared to pre-treatment levels in Group $1(\mathrm{p}<0.01)$.

Cite As: Taş S, Tuğcu V, Karadağ S, Şahin S, Taşçı Aİ. Preventive effect of pomegranate juice on ESWL-related renal damage in patients with kidney stones. New J Urol. 2022; 17(1):22-30. DOI: 10.33719/yud.2022;17-1-973916

The study was approved by the University of Health Sciences, Bakırköy Dr.Sadi Konuk Training and Research Hospital (Approval Number: 2009/78, 18.06.2009). All research was performed in accordance with relevant guidelines/regulations, and informed consent was obtained from all participants. 
lendi ( $<<0,01)$.Grup 2'de tedavi sonrası NAG düzeylerinde ortalama $3,44 \pm 5,21$ düzeyinde artı̧ gözlendi $(p<0,01)$.

Sonuç: Çalışmamızda NS’nin ESWL'ye bağlı böbrek hasarı üzerine koruyucu etkisi olduğunu gösterdik.

Anahtar Kelimeler: Antioksidan, böbrek taşı, taş kırma, nar suyu.
There was a statistically significant mean increase of $3.44 \pm 5.21$ and $13.07 \pm 5.50$ in Groups 2 and 3, respectively ( $<0.01 ; \mathrm{p}<0.01$, respectively).

Conclusion: Our study concluded that pomegranate juice (PJ) has protective effects against ESWL-related renal damage.

Keywords: Antioxidant, kidney stones, lithotripsy, pomegranate juice.

\section{INTRODUCTION}

Extracorporeal Shock Wave Lithotripsy (ESWL) is an effective non-invasive method for treating urinary stones (1). However, it has damaging effects on the renal parenchyma and surrounding tissues. There are poorly understood mechanisms underlying ESWL-induced renal damage (2). ESWL-induced renal damage has poorly understood underlying mechanisms, including thermal and impact effects, the transient decline in renal perfusion, and the generation of free radicals due to ischemic cell damage and oxidative stress (3). There is a striking similarity between ESWL-related histopathological changes and ischemia-related findings in the kidney (4).

There are high $\mathrm{N}$-acetyl-beta-D-glucosaminidase (NAG) levels, especially in lysosomes in renal proximal tubule cells. An increase in NAG levels in the urine indicates renal tubular dysfunction. A marked increase in diuresis and NAG excretion and a transient decrease in osmolality have been demonstrated after ESWL. These are indicators of tubular dysfunction caused by ESWL $(5,6)$.

8-Hydroxy deoxyguanosine (8-OHdG) is a molecule that arises from oxidative stress, causes cellular injury by interfering with the structure of biological macromolecules

such as lipids, proteins, and DNA. Measurement of 8 -OHdG levels is accepted as a direct marker of oxidative damage in DNA, which is the most commonly used method to determine the levels of oxidative DNA damage $(7,8)$.

ESWL causes a transient increase in EPO levels independent of hemoglobin levels. This increase is attributed to intrarenal microcirculatory disorders resulting in tissue hypoxia (9).
Pomegranate juice is rich in polyphenol antioxidants. Polyphenols are the most abundant dietary antioxidants. These polyphenols include tannins and anthocyanins. These antioxidants are stronger than vitamin E, vitamin C, Qenzim10, and similar antioxidants (10). Pomegranate juice has been shown to have antioxidant effects against lipid peroxidation. Polyphenols are protective against reactive oxygen species produced intracellularly and extracellularly. The polyphenol content of pomegranate juice is between $0.2-1 \%$, which varies between species. Pomegranate juice has a strong antioxidant effect, which further potentiates the biological effects of nitric oxide synthesis (eNO) $(11,12)$.

Faria et al. reported that PJ has a protective role against hepatic protein and DNA oxidation, and systemic oxidative stress (13). Kaur et al. reported that pomegranate extract could scavenge superoxide $(\mathrm{O}(2)$ up to $53.3 \%, \mathrm{H} 2 \mathrm{O} 2$ up to $30 \%$, 'OH radicals up to $37 \%$ and nitric oxide (NO) up to $74.5 \%$ and reduce hepatic lipid oxidation caused by 'OH radicals (14). Rosenblat et al. showed that pomegranate juice reduces the severity of atherosclerosis with its strong antioxidant effects (11).

This study measured NAG and 8-OHdG levels as an indicator of oxidative stress after ESWL, erythropoietin (EPO) levels to indicate an intrarenal microcirculatory disorder, and creatinine clearance and blood creatinine levels to indicate an alteration in renal function. It was aimed to show whether pomegranate juice has a protective effect against ESWL-induced renal damage.

\section{MATERIAL AND METHODS}

The pomegranate juice used in our study was prepared in accordance with the food regulations in the laboratories of Istanbul Technical University, Faculty of Chemistry and Metallurgy, Department of Food Engi- 
neering. After washing the fresh pomegranates, their inner and outer skins and seeds were squeezed in a press. It was treated with pectinase enzyme to facilitate the filtration process and prevent pectin gel formation. It was then filtered, posturized, and dried. An extract of $400 \mathrm{~g}$ was obtained from approximately $1 \mathrm{~kg}$ of pomegranate. Subsequently, $10 \mathrm{~g}$ of pomegranate extract was diluted with $90 \mathrm{ml}$ of drinking water and centrifuged at $3000 \mathrm{rpm}$ for 20 minutes. This prepared concentration contained $10 \mathrm{~g}$ of pomegranate juice in every $100 \mathrm{ml}$ $(15,16)$.

We divided patients to undergo ESWL due to renal calculus into three groups containing 30 participants. All patients received 2000 to 2500 shock waves in the range of $18-24 \mathrm{kV}$ (mean 20 with PCK Stonelith-V5 Lithotripter). In the pre-ESWL evaluation, after careful history taking and physical examination, the calculi's number, size, and localization were determined. Any obstruction distal to or any dilatation proximal to the calculi was evaluated with IVP and/or USG. It was ensured that the radiological examinations were performed shortly before the ESWL. Vital signs (pulse, fever, and blood pressure) were evaluated. Preoperatively, we determined BUN and creatinine levels and performed complete blood count and coagulation tests in all patients. The patients were informed about the procedure and its complications. Smokers, patients with hypertension, diabetes, malignancy, and urinary tract infection, patients who had previously undergone ESWL or were operated on for renal calculi, patients who did not accept treatment, and those who had contraindications were excluded from the study.

All patients followed a diet low in vegetables and fruits for 1 week before ESWL. Group 1 (control group) patients received only ESWL treatment. Group 2 (study group) patients were recommended to take $30 \mathrm{ml} / \mathrm{kg} /$ day pomegranate juice mixture orally for 2 days before ESWL. Group 3 (placebo group) patients were recommended to take $30 \mathrm{mg} / \mathrm{kg} /$ day water orally for 2 days before ESWL. In order to measure lipid peroxidation markers showing the DNA lesion associated with oxidative stress and to show tubular damage after ESWL, 24-hour and spot urine samples were collected 3 days before and just after ESWL from patients in three groups. NAG ( 12889 Gregg curt Poway
CA 92064, USA ), 8-OHdG (Vancouver, WA 98662 product NWK-0HDG01), creatinine, sodium, volume, and osmolality levels were measured by complete and 24-hour urine analysis. Venous blood samples were collected from all patients following a 12-hour fasting period 2 days before and 3 hours after ESWL. A $3 \mathrm{ml}$ sample was taken from peripheral venous blood into a dry tube, and the levels of urea, creatinine, and EPO (according to IVDD 98/79/EC MDSS Burckhardstrasse 130163 Hannover, Germany) were measured in the biochemistry laboratory in our hospital on the same day. Creatinine clearance $(\mathrm{mg} / \mathrm{min})$ was calculated using the formula: (urine creatinine $(\mathrm{mg} / \mathrm{dL}) \mathrm{x}$ urine volume $(\mathrm{mL} / 24 \mathrm{~h})$ (serum creatinine $(\mathrm{mg} / \mathrm{dL}) \times 1440$.

\section{Statistical Analysis}

NCSS (Number Cruncher Statistical System) 2007\&PASS 2008 Statistical Software (Utah, USA) package was used for statistical analysis of the results. Descriptive statistical methods (mean, standard deviation) were used to evaluate data. In addition, in comparing quantitative data, the Kruskal Wallis test was used for intergroup comparisons of non-normally distributed parameters, and the Mann-Whitney $U$ test was used to determine the groups responsible for the difference. Paired sample t-test was used for in-group comparisons of normally distributed parameters. The level of statistical significance was set as $\mathrm{p}<0.05$.

\section{RESULT}

There was a statistically significant mean increase of 52.39 \pm 10.49 in $8-O H d G$ levels after treatment compared to pre-treatment levels in Group $1(\mathrm{p}<0.01)$.

There was a statistically significant mean increase of $13.16 \pm 7.71$ and 33.24 \pm 12.82 in Groups 2 and 3, respectively ( $\mathrm{p}<0.01 ; \mathrm{p}<0.01$, respectively)

There was a statistically significant difference between the percentage changes of 8-OHdG levels of the groups. Therefore, pairwise comparisons were made to determine the group responsible for the difference. The percentage change was statistically significantly higher in Group 1 compared to Groups 2 and 3 ( $\mathrm{p}<0.01$; $\mathrm{p}<0.01$, respectively) and in group 2 compared to group 3 ( $p=0.01 ; p<0.01$, respectively). Paired sample $\mathrm{t}$-test $\mathrm{p}<0.05$. 
Table 1. Reviews of 8-OHdG

\begin{tabular}{lllll}
\hline & Control & Pomegranate Juice & Water & P \\
\hline 8-OHdG & Mean \pm SD & Mean \pm SD & Mean \pm SD \\
& $($ Median $)$ & $($ Median) & $32.21 \pm 10.38$ \\
Pre-Treatment & $31.32 \pm 8.72$ & $31.23 \pm 10.24$ & $65.45 \pm 19.12$ \\
Post-Treatment & $83.71 \pm 16.17$ & $44.40 \pm 13.13$ & 0.001 & $110.52 \pm 43.66$ \\
p & 0.001 & 0.001 & $(111.1)$ & 0.001 \\
\hline \% change & $178.25 \pm 55.91$ & $47.85 \pm 39.45$ & $(38.77)$ & \\
\hline
\end{tabular}

Kruskal-Wallis test $p<0.01$

In our study, the increase in 8-OHdG, which indicates DNA damage, was the least in group 2. We established that pomegranate juice protects against oxidative stress. We showed that it provides hydration and protects it from oxidative damage during ESWL.

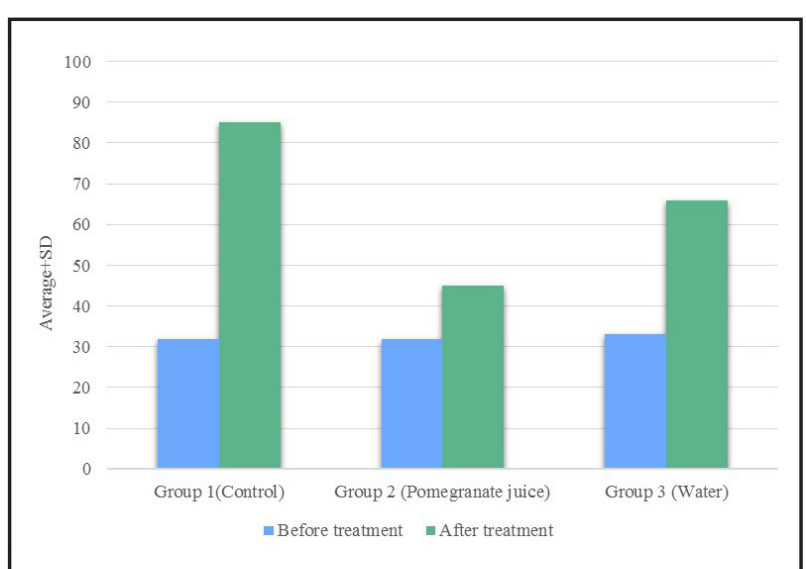

Figure 1. Distribution of $8-\mathrm{OHdG}$ levels between groups before and after treatment

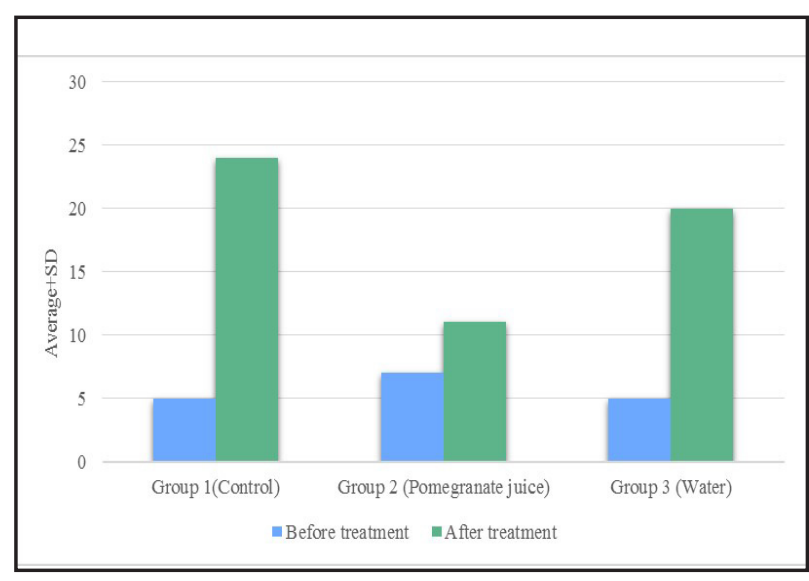

Figure 2. Distribution of NAG levels between groups before and after treatment

Table 2. Increase in NAG levels between groups

\begin{tabular}{|c|c|c|c|c|}
\hline & Control & Pomegranate Juice & Water & $\mathbf{P}$ \\
\hline & Mean \pm SD & Mean \pm SD & Mean \pm SD & \\
\hline NAG & (Median) & (Median) & (Median) & \\
\hline Pre-Treatment & $4.92 \pm 3.0$ & $6.995 \pm 5.64$ & $4.69 \pm 3.79$ & \\
\hline Post-Treatment & $24.12 \pm 5.78$ & $10.40 \pm 4.58$ & $19.56 \pm 6.75$ & \\
\hline $\mathbf{p}$ & 0.001 & 0.001 & 0.001 & \\
\hline \multirow{2}{*}{$\%$ change } & $956.85 \pm 1540.66$ & $158.39 \pm 216.47$ & $444.38 \pm 631.67$ & \multirow{2}{*}{0.001} \\
\hline & $(349.75)$ & $(59.05)$ & (201.8) & \\
\hline
\end{tabular}

Kruskal-Wallis test $p<0.01$

There was a statistically significant mean increase of $19.20 \pm 5.21$ in NAG levels after treatment compared to pre-treatment levels in Group $1(\mathrm{p}<0.01)$.

There was a statistically significant mean increase of 3.44 \pm 5.21 and 13.07 \pm 5.50 in Groups 2 and 3, respectively $(\mathrm{p}<0.01 ; \mathrm{p}<0.01$, respectively). 
There was a statistically significant difference between the percentage changes in the NAG levels of the groups. Pairwise comparisons showed that the percentage change was statistically significantly higher in Group 1 compared to Groups 2 and 3 ( $\mathrm{p}<0.01 ; \mathrm{p}<0.01$, respectively) and in Group 3 compared to Group 2 ( $\mathrm{p}<0.01 ; \mathrm{p}<0.01$, respectively). Paired sample t-test $\mathrm{p}<0.05$. We determined that pomegranate juice significantly reduced tubular dysfunction due to ESWL.

Table 3. Increase in EPO levels between groups

\begin{tabular}{|c|c|c|c|c|}
\hline & Control & Pomegranate Juice & Water & $\mathbf{P}$ \\
\hline & Mean \pm SD & Mean \pm SD & Mean \pm SD & \\
\hline EPO & (Median) & (Median) & (Median) & \\
\hline Pre-Treatment & $36,6744.95$ & $39,0349.26$ & 35.7547 .13 & \\
\hline Post-Treatment & 74.04410 .51 & 75.61148 .52 & 75.69413 .01 & \\
\hline $\mathbf{p}$ & 0.001 & 0.001 & 0.001 & \\
\hline \multirow{2}{*}{$\%$ change } & 106.13443 .19 & 98.52451 .62 & 120.67464 .56 & \multirow{2}{*}{0.115} \\
\hline & $(102.95)$ & $(84.41)$ & $(118.79)$ & \\
\hline
\end{tabular}

Kruskal-Wallis test $p<0.01$

There was a statistically significant mean increase of $37.37 \pm 11.99$ in EPO levels after treatment compared to pre-treatment levels in Group $1(\mathrm{p}<0.01)$.

There was a statistically significant mean increase of $36.57 \pm 16.14$ and $37.37 \pm 11.99$ in Groups 2 and 3, respectively $(\mathrm{p}<0.01 ; \mathrm{p}<0.01$, respectively). We established that pomegranate juice is protective in intrarenal microcirculatory disorder due to ESWL.

There was a statistically significant difference between the percentage changes of EPO levels of the groups.

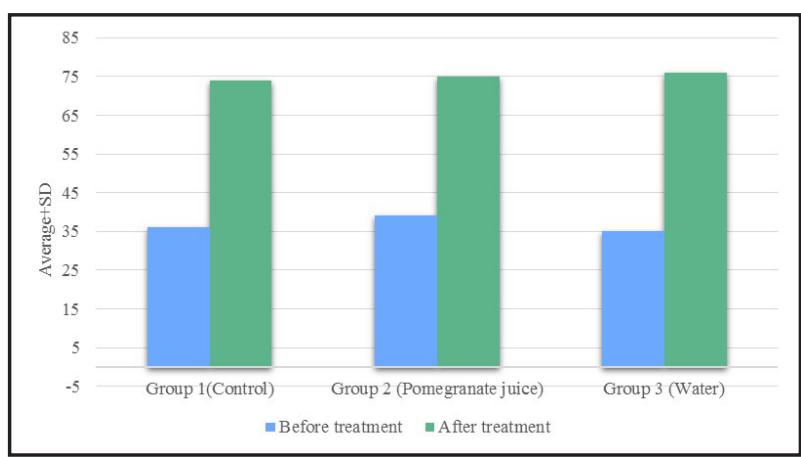

Figure 3. Distribution of EPO levels between groups before and after treatment

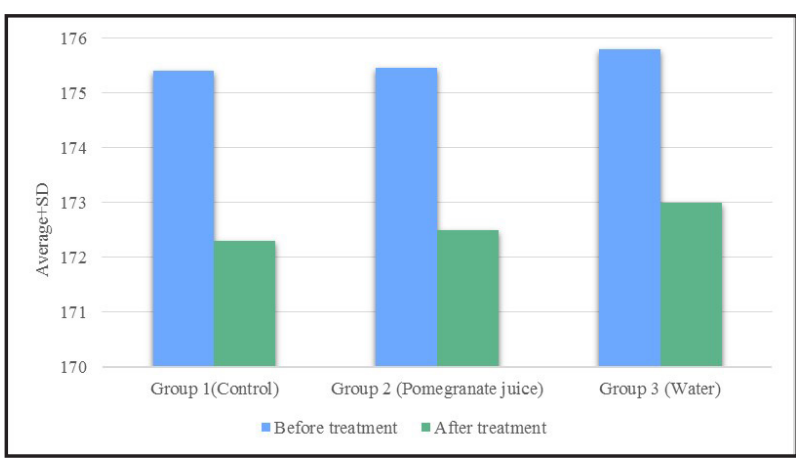

Figure 4. Distribution of clearance levels between groups before and after treatment

Table 4. Changes in Clearance by Groups

\begin{tabular}{llll}
\hline & Control & Pomegranate Juice & Water \\
\hline Clearance & Mean \pm SD & Mean \pm SD & Mean \pm SD \\
\hline Pre-Treatment & $($ Median $)$ & (Median) & $($ Median $)$ \\
Post-Treatment & $175.5 \pm 1.85$ & $175.5 \pm 1.85$ & $175.8 \pm 1.60$ \\
p & $172.53 \pm 1.71$ & $172.53 \pm 1.71$ & $173.16 \pm 1.64$ \\
\% change & 0.001 & 0.001 & 0.001 \\
\hline
\end{tabular}

Kruskal-Wallis test $p<0.01$ 
There was a statistically significant mean decrease of $32.96 \pm 1.12$ in clearance levels after treatment compared to pre-treatment levels in Group $1(\mathrm{p}<0.01)$.

There was a statistically significant mean decrease of $2.96 \pm 1.12$ and $2.63 \pm 0.92$ in Groups 2 and 3 ( $p<0.01$; $\mathrm{p}<0.01$, respectively). Paired sample t-test $\mathrm{p}<0.05$.

\section{DISCUSSION}

ESWL has been accepted as an effective non-invasive treatment of urinary tract stones. There is a striking similarity between ESWL-related histopathological changes and ischemia-related findings in the kidney. It has been accepted that there is an ischemia formation in the renal parenchyma distal to the lesion associated with damage to the intrarenal vessels $(17,18)$. After ischemia, the tissue is exposed to hypoxia, resulting in hypoxic tissue damage. Prolonged ischemia leads to loss of integrity of cells and even cellular death. The production of free oxygen radicals (FOR) is a normal physiological phenomenon. However, the increase in the synthesis of FORs leads to oxidation and DNA damage in cells $(19,20)$.

Free radical inhibitors are effective in most of the total damage caused by the reperfusion component. For a successful timing of the prevention of lipid peroxidation, it is important to administer antioxidants before or at the time of reperfusion (21). In our study, PJ with antioxidant properties was started to be given 2 days before ESWL.

It has been reported that oxidative stress can cause DNA damage such as base modifications and strand breaks. Among the base modifications induced by ROS, 8-OHdG is one of the DNA products with the highest oxidative properties. Hirano et al. reported that urinary and leukocytic 8-OHdG levels were higher in patients with non-insulin-dependent diabetes mellitus (NIDDM) with complications than in patients without complication. They stated that increased oxidative stress induced by hyperglycemia plays a role in the emergence of diabetic complications (7). In our study, we showed that 8-OHdG levels were statistically significantly increased in the urine of all groups after ESWL $(p<0.01)$. This has been attributed to increased oxidative DNA damage as a result of lipid peroxidation after ESWL. We found a statistically significant difference between the groups $(p<0.01)$. There was the lowest increase in Group II (PJ) $(\mathrm{p}<0.01)$. We also showed that when PJ is used as an antioxidant, it protects from oxidative DNA damage, and there was a statistically significant difference between Groups 1 and $3(\mathrm{p}<0.01)$. Moreover, we found that hydration before ESWL reduces oxidative DNA damage $(\mathrm{p}<0.01)$.

Hinokio et al. showed increased urinary NAG levels after ESWL compared to pretreatment levels. They attributed this increase to the damage on the proximal tubule after ESWL (22). In an animal study, Biri et al examined the effects of the combination of antioxidant vitamins $\mathrm{C}$ and $\mathrm{E}$ in the renal tissues of rabbits after ESWL. They showed a lower increase in NAG and malodialdehyde (MDA) levels in the antioxidant group (23). In an animal study, Özguner et al. used caffeic acid phentanyl ester (CAPE) as an antioxidant to prevent oxidative stress-induced renal tubular damage after ESWL. They divided the rabbits into two groups and administered CAPE in one group. They measured urinary NAG and malodialdehyde (MDA) levels before and after ESWL in both groups. They showed a higher increase in the ESWL group than in the CAPE group. They showed that ESWL causes damage to renal tubules due to oxidative stress, which can be prevented by antioxidants (24). In our study, a diet low in green vegetables and fruits was followed for 1 week in order to prevent any antioxidant intake in all groups.Two days before ESWL, PJ was started orally as an antioxidant at a dose of $2 \mathrm{mg} / \mathrm{kg} /$ day. There was an increase in urinary NAG levels after ESWL in all groups $(\mathrm{p}<0.01)$. We interpreted that the increase in NAG levels is associated with renal tubular damage due to oxidative stress after ESWL. There was a statistically significant difference in 
the increase between the groups $(\mathrm{p}<0.01)$. The control group had the highest increase in urinary NAG levels $(\mathrm{p}<0.01)$. We showed a lower increase in group 2 compared to the other groups $(\mathrm{p}<0.01)$. We showed that oxidative stress after ESWL can be reduced with PJ used as an antioxidant. We showed that the difference between groups 1 and 3 was due to the reducing effect of pre-ESWL hydration on renal tubular injury $(\mathrm{p}<0.01)$.

Eterović et al. showed that ESWL caused a transient increase in EPO levels independent of hemoglobin levels. This increase is attributed to intrarenal microcirculatory disorders resulting in tissue hypoxia (25). In an animal study on pigs, Willis et al established 3 groups: ESWL only (Group 1); ESWL after verapamil (Group 2); and sham (Group 3). In their study, GFR and RPF were measured for both kidneys. In group 1, there was a decrease in GFR and RPF after 1 hour in the kidney that was subjected to ESWL. In the other kidney, there was no change in GFR, but there was a decrease in RPF. These changes showed an improvement after 24 hours. In the verapamil group, there was a decrease in GFR and RPF after 1 hour in the kidney subjected to ESWL, but there was an increase in GFR and RPF in the other kidney. This has been attributed to vasoconstriction during ESWL (26).

We showed that PJ, used as an antioxidant, had no effect on the increase of EPO and the decrease of GFR. We attributed the increase in EPO and decrease in GFR 3 hours after ESWL to vasoconstriction in the renal parenchyma and intrarenal microcirculatory disorders.

\section{CONCLUSION}

ESWL-induced kidney damage leads to ischemia-reperfusion imbalance, vasoconstriction by direct action, and ultimately to oxidative stress as a result of intrarenal microcirculation disorder. We have shown that $\mathrm{PJ}$ is protective against oxidative stress when given before ESWL. We have shown that providing adequate hydration also protects against ESWL-induced oxidative damage. Therefore, high fluid intake may help protect against oxidative stress caused by ESWL. In this study, we showed that PJ can be used as an antioxidant.

\section{Conflict of interest}

The authors declare to have no conflicts of interest.

\section{Financial Disclosure}

The authors declared that this study has received no financial support.

\section{Informed Consent}

Informed consent was obtained from all individual participants included in the study.

\section{Ethical Approval}

The study was approved by the University of Health Sciences, Bakurköy Dr.Sadi Konuk Training and Research Hospital (Approval Number: 2009/78, Approval Date: 18.06.2009) and written informed consent was received from all participants. The study protocol conformed to the ethical guidelines of the Helsinki Declaration.

\section{Author Contributions}

Conception and design; ST, VT, Data acquisition; ST, SŞ, SK, Data analysis and interpretation; ST, VT, Drafting the manuscript; ST, Critical revision of the manuscript for scientific and factual content; ST, VT, Statistical analysis; ST, VT, Supervision; VT.

\section{REFERENCES}

1. Aksoy Y, Malkoc I, Atmaca A, et al. The effects of extracorporeal shock wave lithotripsy on antioxidant enzymes in erythrocytes. Cell Biochemistry and Function: Cellular biochemistry and its modulation by active agents or disease, 2006; 24(5):467-469.

2. Chaussy C,H Walter Brendel, and E Schmiedt. Extracorporeally induced destruction of kidney stones by shock waves. The Lancet 316. 1980;8207:1265-1268.

3. Karlsen J, Smevik B., Stenstrom, et al. "Acute physiological changes in canine kidneys following exposure to extracorporeal shock waves." The Journal of urology. 1990; 143(6):1280-1283.

4. Fegan JE, Hausmann DA, Alexander M. Preservation of renal architecture during extracorporeal shock wave lithotripsy. J Endourol. 1991; 5: 273-276. 
5. Willis RL. Evan AP, Connors BA, et al. Effects of extracorporeal shock wave lithotripsy to one kidney on bilateral glomerular filtration rate and PAH clearance in minipigs. J Urol 1996; 156:1502-1506.

6. Kishimoto T, Senju M, Sugimoto T. Effect of high energy shock wave exposure on renal function during extracorporeal shock wave lithotripsy for kidney stones. Eur Urol 1990;18: 290.

7. Hirano T, Yamaguchi R, Asami S, et al. Kasai H. 8-Hydroxyguanine levels in nuclear DNA and its repair activity in rat organs associated with age. The Journal of Gerantology 1996;51:303-305.

8. Kasai H. Analysis of a form of oxidative DNA damage, 8-Hydroxy-2'-deoxyguanosine, as a marker of celluler oxidative stress during carcinogensis. Mutation Research. 1997; 387:147-63.

9. T Vögeli, B Schmitz-Dräger, HE Mellin, et al. "Changes in Erythropoietin Serum Levels by Extracorporeal Shock Wave Lithotripsy." Urologia internationalis. 1990; 45(2):92-94.

10. Rice.E, Catherine A, Nicholas J, et al. Structure-antioxidant activity relationships of flavonoids and phenolic acids. Free radical biology and medicine 1996; 20(7):933-956.

11. Rosenblat M, Volkova N, Coleman R, et al. Pomegranate byproduct administration to apolipoprotein edeficient mice attenuates atherosclerosis development as a result of decreased macrophage oxidative stress and reduced cellular uptake of oxidized low-density lipoprotein. J Agric Food Chem. 2006; 54:1928-1935.

12. Kaur G, Jabbar Z, Athar M, et al. Punica granatum (pomegranate) flower extract possesses potent antioxidant activity and abrogates Fe-NTA induced hepatotoxicity in mice. Food Chem Toxicol. 2006; 44:984-993.

13. Faria A, Monteiro R, Mateus $\mathrm{N}$, et al. Effect of pomegranate (Punica granatum) juice intake on hepatic oxidative stress. Eur J Nutr. 2007; 46:271-278.

14. Kaur G, Jabbar Z, Athar M, et al. Punica granatum (pomegranate) flower extract possesses potent antioxidant activity and abrogates Fe-NTA induced hepato- toxicity in mice. Food Chem Toxicol. 2006; 44: 984-993.

15. Rosenblat M, Hayek T, Aviram M. Anti-oxidative effects of pomegranate juice (PJ) consumption by diabetic patients on serum and on macrophages. Atherosclerosis 2006; 187: 363-371.

16. Aviram M, Domfeld L, Rosenblat M, et al. Pomegranate juice consumption reduces oxidative stress, atherogenic modifications to LDL, and platelet aggregation: studies in humans and in atherosclerotik apolipoprotein E-deficient mice. Am J Clin Nurt. 2000; 71:1062-76.

17. Evan, A. P. Willis, L. R., Lingeman, et al. Renal trauma and the risk of long-term complications in shock wave lithotripsy. Nephron 1998; 78(1):1-8.

18. Fegan JE, Hausmann DA, Alexander M. Preservation of renal architecture during extracorporeal shock wave lithotripsy. J Endourol 1991; 5:273-276.

19. E Rhoden, C Telöken, M Lucas Rhoden, Ernani, et al. Protective effect of allopurinol in the renal ischemiareperfusion in uninephrectomized rats. General Pharmacology: The Vascular System 2000; 35(4):189-193.

20. Serel TA, Özgüner F, Soyupek S. Prevention of shock wave induced renal oxidative stres by melatonin: an experimental stuyd. Urol Res. 2004; 32:69-71.

21. Tugcu V, Kemahli E, Ozbek E, et al. Protective effect of a potent antioxidant, pomegranate juice, in the kidney of rats with nephrolithiasis induced by ethylene glycol. Journal of Endourology 2008; 22(12):2723-2732.

22. Hinokio Y, Suziki S, Chiba M, et al. Oxidative DNA damage in diabetes mellitus: its association with diabetic complications. Diabetologia. 1999; 42(8):995-8.

23. Biri H,Ozturk HS, Buyukkoçak S, et al. Antioxidant defense potential of rabbit renal tissue after ESWL: proctective effects of antioxidant vitamins. Nefron. 1998; 79:181-185.

24. Ozguner F, Armağan A, Koyu A, et al. A novel antioxidant agent caffeic asid phenethyl ester prevents shock wave-induced renal tubuler oxidative sters. Urol Res. 2005; 33:239-243.

25. Eterović D, Šitum M. Punda A et al. "Urinary obstruction depresses erythropoiesis which recovers after pa- 
renchyma-saving surgery but not SWL." Urological research 2010; 38(1):51-56.

26. Willıs L, R Evan A, P Connors et al. Effects of extracorporeal shock wave lithotripsy to one kidney on bilateral glomerular filtration rate and PAH clearance in minipigs. The Journal of urology, 1996, 156.4: 1502-1506. 